GLOBAL JOURNAL OF EDUCATIONAL RESEARCH VOL 15, 2016: 7-22

COPYRIGHTC BACHUDO SCIENCE CO. LTD PRINTED IN NIGERIA. ISSN 1596-6224 www.globaljournalseries.com; Info@globaljournalseries.com

\title{
TEACHING PRACTICE EXPERIENCES OF NURSING STUDENTS: A COMPARISON BETWEEN DIRECT ENTRY AND GENERIC STUDENTS OF DEPARTMENT OF NURSING SCIENCE, UNIVERSITY OF CALABAR
}

\author{
MARY ACHI MGBEKEM, EMON DUKE, EMILIA OYIRA, REGINA ELLA, AKON \\ NDIOK, AND MARGARET ARMON
}

(Received 23, October 2015; Revision Accepted 17, November 2015)

\begin{abstract}
An essential part of the nurse education programs is to facilitate the linking of theory to practice. Teaching practice experiences of nursing student provide greater insight to develop effective classroom and clinical teaching strategies in nursing. This paper described teaching practice experiences of nursing students, expectations and benefits for effective learning. The study simulated the complexities of life in a typical classroom that facilitates learning characterized by an acceptance of responsibility and clinical decision making in nursing practice using a mixed research design. A structured questionnaire was used to elicit information from One hundred and fifteen (115) students, 38 direct entry and 77 generic fourth year students while ten students (five direct and five generic) participated in the focused group discussion (FGD). Descriptive data were analyzed using SPSS vision 18 to obtain frequencies, percentages mean and standard deviation and chi square findings. The FGD based on their categories were divided into two groups. The data collected was analyzed by coding and categorizing the themes that emerged. Quantitative analysis revealed significant $\left({ }^{* *} p<0.001\right)$ chi square rejecting the null hypotheses at 0.05 with probabilities less than 0.001 . This shows that nursing students' experiences, expectations and benefits are significantly derived from teaching practice although contingent on the mode of entry into the university (Direct entry and Generic entry). It is concluded that teaching practice is a motivating and challenging method that necessitates learning of facts, principles and procedures for effective development of decision-making skills that assist nursing students assume responsibility. It is recommended that more time be allotted for this important exercise especially for generic students.
\end{abstract}

\section{KEYWORDS: Nursing Student, Teaching Experiences, Expectation, benefits, Teaching Practice}

\section{INTRODUCTION}

The intent of pre-registration nurse education in Nigeria is to prepare students who are fit for practice at the point of registration (N\&MCN, 2006) to enable them be registered with the Nursing and Midwifery Council of Nigeria
(N\&MCN) in order to gain employment in various fields of nursing. Practical experience is one of the means of acquiring knowledge, skills and values essential to professional practice. It gives opportunity for the learner to become socialized into a profession through gaining of competence in practice since theoretical knowledge is put to

Mary Achi Mgbekem, Department of Nursing Science, University of Calabar, Calabar, C.R.S, Nigeria.

Emon Duke, Department of Nursing Science, University of Calabar, Calabar, C.R.S, Nigeria.

Emilia Oyira, Department of Nursing Science, University of Calabar, Calabar, C.R.S, Nigeria.

Regina Ella, Department of Nursing Science, University of Calabar, Calabar, C.R.S, Nigeria.

Akon Ndiok, Department of Nursing Science, University of Calabar, Calabar, C.R.S, Nigeria.

Margaret Armon, Department of Nursing Science, University of Calabar, Calabar, C.R.S, Nigeria. 
use for the benefit of the learner and consumer. During field-based experience, learners have the opportunity to use their teaching practice experiences to regularly apply pedagogical theory and course learning to assist them to develop as skilful, knowledgeable and reflective thinkers, a tool essential in nursing practice. The reflective mind enables them develop questioning ability that improves practice. Teaching is a human activity, a social phenomenon and a system of actions designed and intended to bring about learning. Professional teaching is an intenti onal activity that aims to facilitate learning charac terizeby an acceptance of responsibility, commit ment and accountability (Manion, 2011). Penn, Wilson \& Rosseter (2008), Berwick, 2011) state that "teaching is a rich and rewarding pursuit for nurses looking to share their clinical expertise with those entering the profession or nurses returning to practice with advanced preparation". One of the strongest motivators to teach is that teaching provides an opportunity to influence student success and shape the next generation of nurses. As an educator, one can model professional values and skills, and ultimately influence the quality of care provided by future nurses.

Client teaching according to Quinn (2001) is a major aspect of nursing practice and an independent nursing function. The importance of client teaching is stressed by the America Hospital Association in 1992 with a Patient Bill of Right; mandating client education as a right. Legislation related to Nursing includes teaching as a function of Nursing, thus making teaching a legal and professional responsibility (American Association of Colleges of Nursing (2008a \& 2008b, America Nurses Association, 2010).

\section{REVIEW OF RELATED LITERATURE}

Teaching practice is an essential component of nurse education as it creates a perfect simulation practicum setting that encompasses th e promotion of cultural diversity. Teaching is a rich and rewarding pursuit for nurses looking to share their clinical expertise with those entering the profession or nurses returning to practice with advanced preparation (Herinckx, Munkvold, Winter, \& Tanner, 2014). One of the strongest motivators to teach is that teaching provides an opportunity to influence student success and shape the next generation of nurses. Teaching is a rich and rewarding pursuit for nurses looking to share their clinical expertise with those entering the profession or nurses returning to practice with advanced preparation. As an educator, one can model professional values and skills, and ultimately influence the quality of care provided by future nurses (Bartels, 2007).

Kiggundu \& Nayimuli (2009) state that te aching practice is a teaching/learning method that combines powerful educational technologies and proven learning strategies to build a selfpaced technology-enhanced environment. Stover (2008), sees teaching practice as a two-way learning experience in the field-based program since students being taught also have something to contribute. He further asserts that teaching within a particular environment for a required minimum of contact hours enabled students to engage in teaching experiences in a safe place where they are supported. Manion (2011), states that effective learning occurs when learners are properly coached and groomed for their expected roles performance. During the nurse preparation periods, Manion (2011) opined, two major things are established (the formation of relationships and the application of principles of motivation) since teaching activities require the ability to understand facts, appreciate the implications and assume responsibility to consequences of decision making during teaching within the context of a contrived but an authentic situation so as to become competent, assertive and efficient teachers/caregivers in the work environment after graduation.

Bell, (2004), Bartels, (2005) assert that teaching practice with the support of a mentoring teacher provides the student teachers a field based program opportunity to use the teaching practice experiences to regularly apply educational theory and course learning to develop skillful knowledgeable reflective professionals (nurses). Mentoring teachers thus play key role in the student teacher's education process and help in stepping up efforts to mentor nursing students and enlighten them about the many benefits that come with a teaching while caring (Bartels, 2007, Maphosa, Shumba \& Shumba, 2007).

A favorable and helpful learning setting for nursing students, Mabuda, Potgieter \& Alberts (2008), Wanekezi, Okoli \& Mezieobi (2011) say 
depends on the availability of placement support systems, like schools, supervision, mentorship an $\mathrm{d}$ relationships between the faculty members and nursing students. Learning in practice placement require conducive environment that provides the appropriate support from skilled practitioners and educators and encourage feedback to the mentoring teacher on advise, correction and suggestions to improve classroom management skills. A practice setting rich in learning experiences, but lacking a supportive environment, discourages the learning in seeking experience and results in the loss of learning and growth opportunities. Practical teaching in nursing is important because the teaching/learning process involves dynamics interaction between teachers and learners as each participant communicates information, emotion, perception and attitude.

These activities of nurse education range from formal academic type of teaching through to the impromptu teaching that occurs spontaneously in the day-to-day work (Quinn, 2000 Maloney, 2008). This teaching method is based on the belief that learning is most efficient and effective when it is situated in realistic settings where learners are clear, not only about the reasons for learning but the context or the ecology of their learning environment. Teaching practice thus creates situations that are not only motivating and challenging, but that necessitates learning of facts, principles and procedures, especially when a Goal-Based Scenario (GBS) is used (Wanekezi, Okoli \& Mezieobi, 2011). A Goal-Based Scenario (GBS) is essentially a simulation in which learners assume a main role (Quinn, 2001, Wanekezi, Okoli \& Mezieobi, 2011).

\section{THEORETICAL FRAMEWORK}

Constructivism Theory (Concept to Classroom, 2004) was adopted for the study. Constructivism Theory is a holistic approach to Teaching and Learning. The theory is based on observation and scientific study about how people learn. It says that people construct their own understanding and knowledge of the world, through experiencing things and reflecting on those experiences. In the classroom, the constructivist view of learning can point towards a number of different teaching practices. In general sense, it usually means encouraging students to use active techniques (experiments, real-world problem solving) to create more knowledge and then to reflect on and talk about what they are doing and how their understanding is changing.

\section{TEACHING PRACTICE ESSENCE}

In nursing, the "goal" of the students is to accomplish the mission or task associated with the main role in a given scenario. In order to achieve this goal, American Nurses Association (2010) asserts that learners should be prepared adequately to meet with challenges of current healthcare trends to cope and compete favourably in the healthcare market after acquiring knowledge, skills and judgment abilities to enhance role performance of professional issues. Goals in this context refer to the successful completion of the task at hand, not the achievement of grades. Quinn (2001) asserts that setting goals motivate learners to "learn by doing." Teaching practice is usually organized to accomplish goal targeted learning outcomes as it is organized around "performance" skills. This action enables the specified task be performed $b$ $y$ the learners (student). Teaching practice thus $p$ rovides opportunity for a prospective nurse to pla $\mathrm{n}$ lessons and experience what it takes to be in $\mathrm{c}$ harge of a group of people while under the super vision of a more experienced teacher (Buerhaus, Staiger \& Auerbach, 2008, Wagaman, 2010)

Although teaching practice is an important learning method, it has been observed that many students during this exercise report experiences they never envisaged before going to the field. These include feeling overwhelmed with requirement for teaching, feeling of lack of adequate preparation for the new assignment as teachers, stage fright to be in control of the class and surprised by the intense course work required, time needed to prepare lesson notes, correction of the notes by supervisors, anticipated opportunities for actual teaching sessions that often results in tension and fear of the outcome of the teaching (Siler and Kleiner, 2007, Solem and Foote, 2004). Given the critical importance of practical nurse education, understanding these issues is essential to creating approaches that would enhance and strengthen the quality of teaching and learning among nursing students.

This mixed study was therefore designed to explore nursing students experiences (NSTE) 
during teaching practice, with a view to identifying problems that need intervention for subsequent group of students.

\section{PURPOSE}

The purpose of the study was to explore the experiences of nursing students during teaching practicum.

The objectives of the research were to:

- Explore the experiences of student nurses during clinical practice.

- Identify factors associated with improvement of learning during teaching practice.

- Determine perceived benefits from teaching practice

\section{RESEARCH QUESTIONS}

The following research questions were asked to guide the study.

- What experiences do nursing students
describe during teaching practice?
How do these experiences compare to
their expectations and needs?
What do nursing students benefit from
the mentors/preceptors experiences
during teaching practice?

\section{Hypothesis}

There are no significant experiences, expectations and benefits derived from teaching practice by nursing student teachers.

\section{Delimitations of the study}

This study focused only on fourth year nursing students in the department of Nursing Science, University of Calabar, Nigeria. The findings could therefore not be generalized to other Universities offering nursing programs.

\section{METHODS}

\section{Research design}

The purpose of the study was to explore the experiences of nursing students during teaching practicum using a mixed research method. The selection criterion for the study was based on the research participants being fourthyear nursing students on teaching practice. One hundred and thirty (130) students were asked to participate through a letter of invitation that informed them of the research theme. One hundred and twenty five (125) students accepted the invitation to participate in the study. One hundred and fifteen were purposively given questionnaire while 10 participants were involved in focused group discussion. The participants were posted to different health institutions of learning in Calabar for the teaching practice. They were briefed on the purpose of the study and duly informed that participation was voluntary and participants' identity will not be revealed to maintain confidentiality.

\section{Data collection}

Data collection for the study was through a 27- item questionnaire with nine (9) items each for experience, expectations and benefits. Section A elicit information on socio-demographic data of the students, section B sought information on teaching practice experiences, areas of expectations expressed by the students and benefits of teaching practice using the questionnaire items. An adapted Likert scale was used and the response weightings were Strongly Agree $(S A)=4$, Agree $(A)=3$, Disagree $=2$, Strongly Disagree $(S D)=1$. The average of these points is $2.50(4+3+2+1)=10 / 4=2.50$. This was used in data analysis. A 27 item questionnaire validated by three experts had a Cronbach Alpha co-efficient of 0.87 degree of reliability from a pretest administered to twenty students run from outside the actual sample for the study. Data were collected by the researchers distributing the questionnaire and same retrieved on the spot.

The phenomenological data was collected through focus group discussion using the research questions as a guide. One focus group interview was conducted in 2013 academic session as students were at that time on field practice. Two categories of students participated in the group discussion session. Generic students (these are students that came direct from secondary schools) and direct entry (those with basic nursing education). Invitation to participate was through a letter given to ten (10) students (5 direct entry and 5 generic) who accepted to participate in the study. The researchers created a forum for questions and answers for the anticipated participants regarding the study. This forum provided a perfect face-toface opportunity to give the consent letters. A date and time for the interview was chosen by the 
participants and the researchers. A confidentiality agreement was signed by one member of each focus and the lead author of the study. Phenomenological interview was used to collect the data because it provides participants with the opportunity to fully describe their experiences (Munhall, 2001). The interviews took place in the department of Nursing Science to allow data generation take place in a familiar setting sin ce personal meaning is tied to background (Burn \& Grove, 2009). The background is important in o rder to uncover and understand the participants' experiences and perspectives within this context. The researchers established rapport with the groups and ensured that the interview began with a clear direction and an indication of the themes to be explored (Burn \& Grove, 2009). Ground rules were made for the focus groups to ensure students knew what to expect. The groups were informed that confidentiality relating to any information shared during the interview and the study in general was important. They were also reminded of their right to decline to answer any question. The interview took one hour ten minutes per group. Each focus group was asked an open-ended question and allowed to discuss freely while using prompts and probes linking to the four themes.

\section{Data Analysis}

Descriptive data analysis using mean rating was adopted. The decision role is that a mean of 2.50 and above indicates agreement with the item statement. The null hypothesis was tested using chi square Analysis at $P<0.05$ level of significance. Qualitative data were analyzed using a thematic analysis of the interview transcripts. Initial coding was done with the transcripts read closely, line-by-line and the researchers. A selective (focused coding was done where the researchers used frequently appearing initial codes to sort and synthesize the data. Lastly there was the development of categories (themes) and analytical frameworks from the focused codes.

\section{RESULTS}

Table 1 shows respondents' sociodemographic data. Majority $(67.57 \%)$ of the students were females, $34.78 \%$ between ages ranged $36-40$ years, $27.83 \%$ between ages $25-30$ years. Students' entry status showed that $66.96 \%$ of the respondents were generic students (students fresh from secondary schools) while direct entry students were those with $\mathrm{RN}$ (registered nurses), RM (registered midwives), RPN (registered psychiatry nurses) who are practicing as clinicians in different hospitals). Table 2a shows responses on general perception of nursing students teaching practice experiences. Questions regarding the ability to link theory to practice was expressed by $30.27 \%$, strongly agreed response by direct entry students compared with $16.73 \%$ response by generic students. Acknowledgement that setting teaching goals, objectives and selection of subject matter is not easy was expressed by $33.07 \%$ direct entry students compared with the generic students (16.53\%). The generic stude nts' responses on preparation of lesson notes and acceptance of instructions, corrections, mutual respect and support from assigned mentors varied greatly from the direct entry group as shown on the table. Questioning as a method of evaluation for both teachers and learners was strongly affirmed by direct entry student $53.82 \%$ compared with generic students (7.08\%). All students except $3.5 \%$ acknowledged that large number of students for practice teaching within a school reduces students' actual practice teaching contacts. Using of instructional materials to improve teaching and learning show direct entry $56.44 \%$ compared with $4.46 \%$. Actual teaching although very difficult provides better experiences question show $52.72 \%$ strongly agreed response compared with $12.49 \%$ of generic students.

Responses on areas of expected improvement by students during teaching practice are shown on table $2 \mathrm{~b}$. The findings in the statements revealed that direct entry students are more likely to set goals and objectives to guide learning, build professional networks to share experiences, improve evidence-based practice and transfer theoretical knowledge to practice compared with generic students based on percentage of the responses and the chi square analyses that were significant $\left({ }^{* *} p<0.001\right)$ rejecting the null hypothesis at 0.05 level with probabilities less than 0.001. Develop questioning ability revealed direct entry $(33.07 \%)$ compared with generic (16.53\%) strongly agreed responses with significant $X^{2}=57.749, p=$ value 0.000 . Learning the art of classroom and time management revealed $33.07 \%$ ability compared 
with $16.53 \%$ by generic students. Expectations to develop effective communication skills based on audience and lesson prepared had 33. 09\% for direct entry and generic $2.61 \%$ strongly agreed response. Utilizing mentoring experiences for better teaching and improved personal learning showed that $33.04 \%$ direct entry students' response affirmation compared with $6.96 \%$ generic strongly agreed response.

Benefits of teaching practice as a teaching/learning method is shown on table 2c. Although all students asserted that teaching practice help students to be resourceful and learn the art of time management to be prompt at school and dress decently, the strongly agreed responses showed that direct entry students had $37.78 \%$ response against generic students with $31.82 \%$. Improved teaching using instructional materials was strongly agreed by direct entry students (36.10\%) compared with $15.20 \%$ recorded by generic students. Responses on lesson notes, actual participation in teaching practice and improvement of communication skills findings were direct entry stand at $33.07 \%$, $51.53 \%$ and 19.38 while generic students showed $16.53 \%, \quad 16.27 \%$ and $16.32 \%$ respectively.

Chi square analysis findings of experiences, expectations and benefits derived from teaching practice are presented on each table alongside the mean and standard deviation. This result implies that the null hypothesis is rejected while the alternate hypothesis is accepted. The implication of these results is that experiences, expectations and benefits are significantly derived from teaching practice by nursing students who participate in teaching practice exercise.

TABLE 1: SOCIO-DEMOGRAPHY DATA OF THE RESPONDENTS

\section{CHARACTERISTICS FREQUENCY}

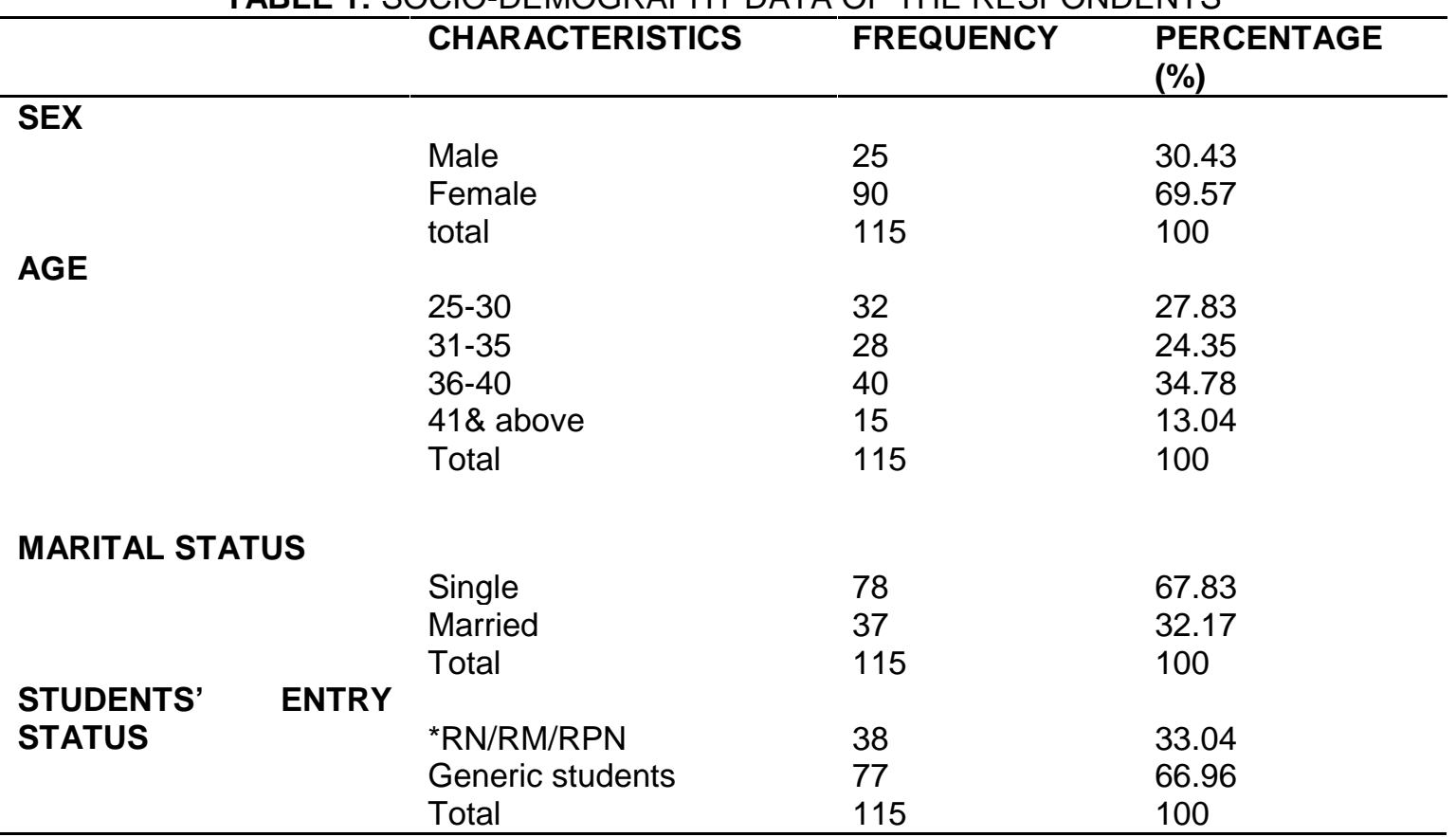


Table 2a: Nursing Student Experiences during Teaching Practice

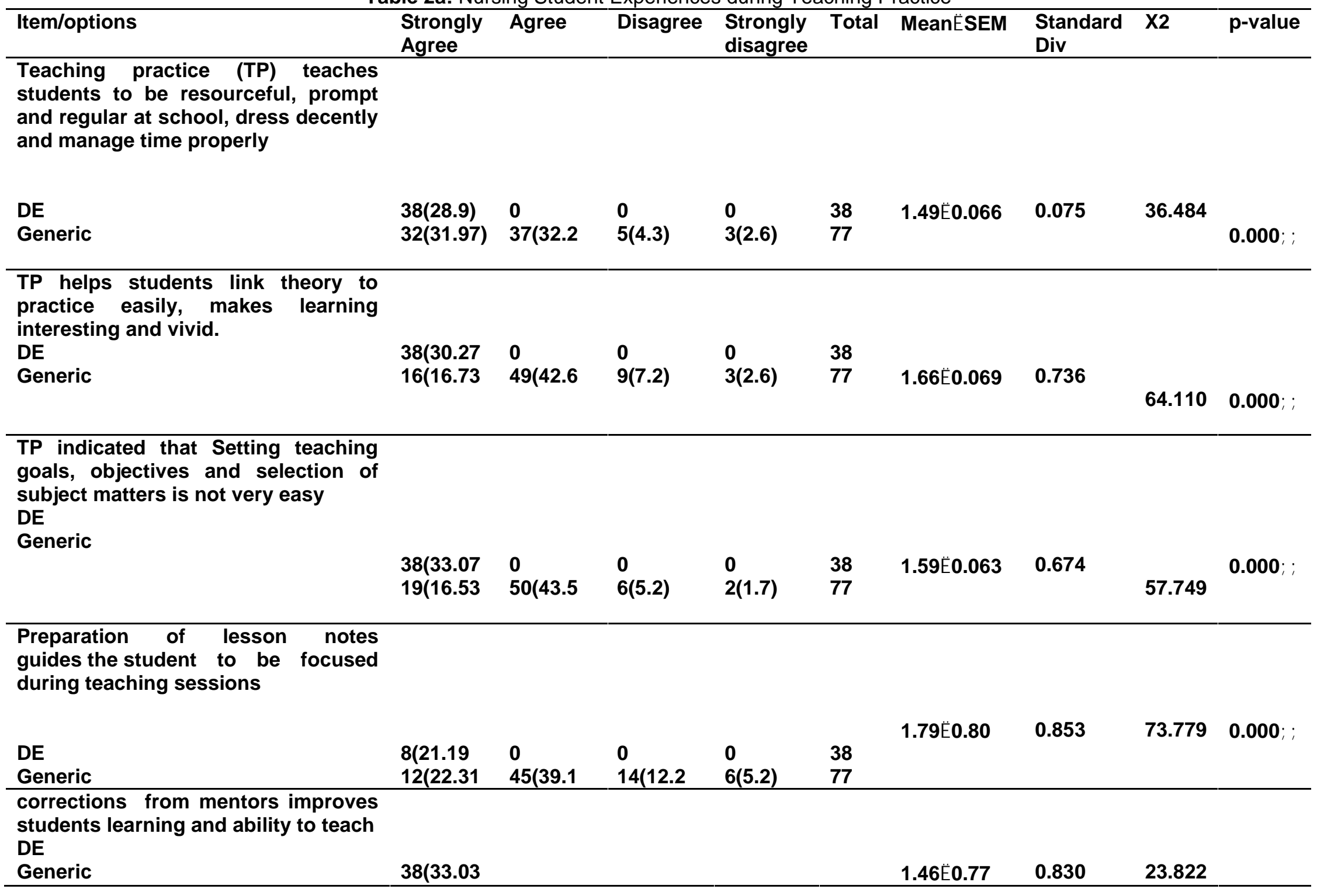




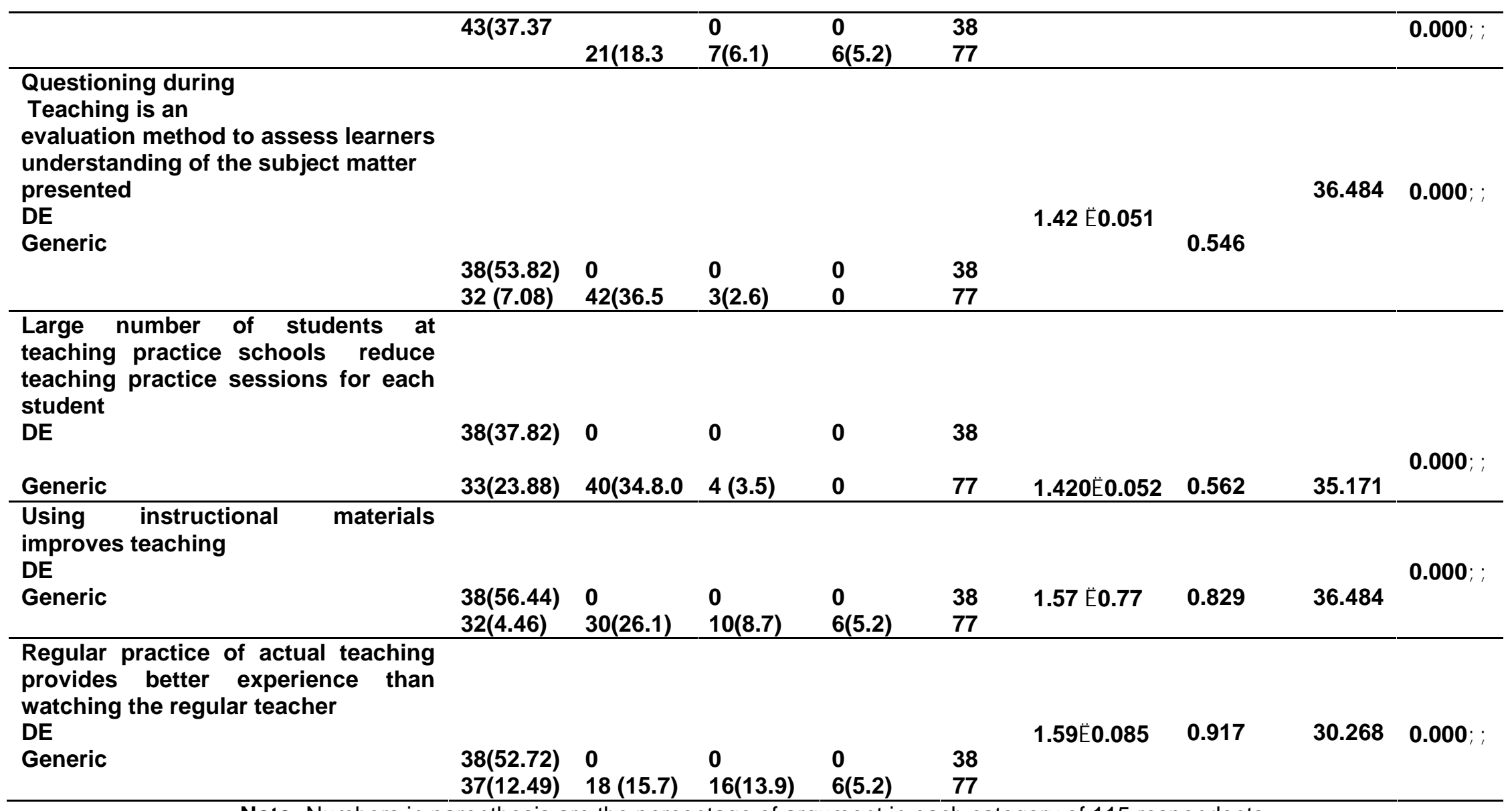

Note: Numbers in parenthesis are the percentage of argument in each category of 115 respondents.

With the Chi-Square statistics significant $(* * p<0.001)$, the null hypothesis is rejected at 0.05 level with the probabilities less than 0.001 .

Conclusion: Nursing student experience is contingent on the Direct Entry and Generic Entry. 
Table 2b: Areas of expectations expressed by the students

\begin{tabular}{|c|c|c|c|c|c|c|c|c|c|}
\hline Item/options & $\begin{array}{l}\text { Strongly } \\
\text { Agree }\end{array}$ & Agree & Disagree & $\begin{array}{l}\text { Strongly } \\
\text { disagreed }\end{array}$ & Total & Mean \pm SEM & $\begin{array}{l}\text { Standard } \\
\text { Div }\end{array}$ & $x^{2}$ & p-value \\
\hline $\begin{array}{l}\text { TP assist students set } \\
\text { goals and objectives that } \\
\text { guide teaching/learning } \\
\text { DE } \\
\text { Generic }\end{array}$ & $\begin{array}{l}38(33.04) \\
57(49.56)\end{array}$ & $\begin{array}{l}0 \\
18(15.7)\end{array}$ & $\begin{array}{l}0 \\
1(0.9)\end{array}$ & $\begin{array}{l}0 \\
1(0.9)\end{array}$ & $\begin{array}{l}38 \\
77\end{array}$ & $1.20 \pm 0.045$ & 0.481 & 11.948 & 0.008 \\
\hline $\begin{array}{l}\text { TP helps students build } \\
\text { professional network and } \\
\text { improve evidence-based } \\
\text { practice } \\
\text { DE } \\
\text { Generic }\end{array}$ & $\begin{array}{l}38(33.04 \\
24(20.87)\end{array}$ & $\begin{array}{l}0 \\
48(41.7)\end{array}$ & $\begin{array}{l}0 \\
3(2.6)\end{array}$ & $\begin{array}{l}0 \\
2(1.7)\end{array}$ & $\begin{array}{l}38 \\
77\end{array}$ & $1.52 \pm 0.060$ & 0.640 & 48.515 & 0.000 \\
\hline $\begin{array}{l}\text { TP helps in transferring } \\
\text { of theoretical knowledge } \\
\text { in practice area } \\
\text { DE } \\
\text { Generic }\end{array}$ & $\begin{array}{l}38(33.04 \\
37(32.17\end{array}$ & $\begin{array}{l}0 \\
35(30.4\end{array}$ & $\begin{array}{l}0 \\
5(4.3)\end{array}$ & $\begin{array}{l}0 \\
0\end{array}$ & $\begin{array}{l}38 \\
77\end{array}$ & $1.39 \pm 0.53$ & 0.573 & 30.268 & 0.000 \\
\hline $\begin{array}{l}\text { TP assist students to } \\
\text { develop questioning } \\
\text { ability to improve inquiry } \\
\text { ability } \\
\text { DE } \\
\text { Generic }\end{array}$ & $\begin{array}{l}38(33.07 \\
19(16.53 \\
\end{array}$ & $\begin{array}{l}0 \\
58(39.1 \\
\end{array}$ & $\begin{array}{l}0 \\
0 \\
\end{array}$ & $\begin{array}{l}0 \\
0 \\
\end{array}$ & $\begin{array}{l}38 \\
77\end{array}$ & $1.50 \pm 0.047$ & 0.502 & 57.749 & 0.000 \\
\hline $\begin{array}{l}\text { TP assist students } \\
\text { acquire to write lesson } \\
\text { notes/method } \\
\text { DE } \\
\text { Generic }\end{array}$ & $\begin{array}{l}38(33.06 \\
42(36.54)\end{array}$ & $29(25.2$ & $\begin{array}{l}0 \\
6(5.2)\end{array}$ & $\begin{array}{l}0 \\
0\end{array}$ & $\begin{array}{l}38 \\
77 \\
\end{array}$ & $1.36 \pm 0.054$ & 0.580 & 24.830 & 0.000 \\
\hline $\begin{array}{l}\text { It improves personal } \\
\text { learning through active } \\
\text { presented } \\
\text { DE } \\
\text { Generic }\end{array}$ & $\begin{array}{l}38(33.06) \\
34(29.56)\end{array}$ & $\begin{array}{l}0 \\
30(26.1\end{array}$ & $\begin{array}{l}0 \\
10(8.7)\end{array}$ & $\begin{array}{l}0 \\
3(2.6)\end{array}$ & $\begin{array}{l}38 \\
77\end{array}$ & $1.51 \pm 0.71$ & 0.765 & 33.894 & 0.000 \\
\hline
\end{tabular}




\begin{tabular}{|c|c|c|c|c|c|c|c|c|c|}
\hline $\begin{array}{l}\text { The art of classroom/time } \\
\text { management is learned } \\
\text { DE } \\
\text { Generic }\end{array}$ & $\begin{array}{l}38(33.07) \\
19(16.53\end{array}$ & $\begin{array}{l}0 \\
45(39.1\end{array}$ & $\begin{array}{l}0 \\
9(7.8\end{array}$ & $\begin{array}{l}0 \\
4(3.5\end{array}$ & $\begin{array}{l}38 \\
77\end{array}$ & $1.65 \pm 0.072$ & 0.773 & 57.749 & 0.000 \\
\hline $\begin{array}{l}\text { TP improves students } \\
\text { communication abilities } \\
\text { DE } \\
\text { Generic }\end{array}$ & $\begin{array}{l}38(33.09) \\
3(2.61)\end{array}$ & $\begin{array}{l}0 \\
44(38.3)\end{array}$ & $\begin{array}{l}0 \\
25(21.7)\end{array}$ & $\begin{array}{l}0 \\
5(4.3)\end{array}$ & $\begin{array}{l}38 \\
77\end{array}$ & $1.95 \pm 0.081$ & 0.867 & $\begin{array}{l}102.43 \\
3\end{array}$ & 0.000 \\
\hline $\begin{array}{l}\text { TP assist students } \\
\text { identify, utilize and } \\
\text { develop } \\
\text { mentors/mentoring } \\
\text { abilities } \\
\text { DE } \\
\text { Generic }\end{array}$ & $\begin{array}{l}38(33.04 \\
8(6.96)\end{array}$ & $\begin{array}{l}0 \\
59(51.3)\end{array}$ & $\begin{array}{l}0 \\
10(8.7)\end{array}$ & $\begin{array}{l}0 \\
0\end{array}$ & $\begin{array}{l}38 \\
77\end{array}$ & $1.69 \pm 0.058$ & 0.626 & 85.130 & 0.000 \\
\hline
\end{tabular}

Note: Numbers in parenthesis are the percentage of argument in each category of 115 respondents.

With the Chi-Square statistics significant $(* * p<0.001)$, we reject the null hypothesis at 0.05 level with the probabilities less than 0.001 .

Conclusion: Nursing student experience is contingent on the Direct Entry and Generic Entry. 
Table 2c: Showing perception of nursing students benefits of teaching practice

\begin{tabular}{|c|c|c|c|c|c|c|c|c|c|}
\hline Item/options & $\begin{array}{l}\text { Strongly } \\
\text { Agree }\end{array}$ & Agree & Disagree & $\begin{array}{l}\text { Strongly } \\
\text { disagree }\end{array}$ & Total & Mean \pm SEM & $\begin{array}{l}\text { Standard } \\
\text { Div }\end{array}$ & $x^{2}$ & p-value \\
\hline $\begin{array}{l}\text { Lesson notes are } \\
\text { great guides for teaching } \\
\text { and learning } \\
\text { DE } \\
\text { Generic }\end{array}$ & $\begin{array}{l}38(33.04 \\
19(16.27\end{array}$ & $\begin{array}{l}0 \\
51(44.3\end{array}$ & $\begin{array}{l}0 \\
6(5.2)\end{array}$ & $\begin{array}{l}0 \\
1(0.9)\end{array}$ & $\begin{array}{l}38 \\
77\end{array}$ & $1.57 \pm 0.059$ & 0.636 & 57.749 & 0.000 \\
\hline $\begin{array}{l}\text { Supervision/mentoring by } \\
\text { teachers ensures quality } \\
\text { outcome } \\
\text { DE } \\
\text { Generic }\end{array}$ & $\begin{array}{l}38(51.53 \\
40(16.27 \\
\end{array}$ & $\begin{array}{l}0 \\
32(27.8\end{array}$ & $\begin{array}{l}0 \\
4(3.5)\end{array}$ & $\begin{array}{l}0 \\
1(0.9) \\
\end{array}$ & $\begin{array}{l}38 \\
77\end{array}$ & $1.37 \pm 0.056$ & 0.599 & 26.921 & 0.000 \\
\hline $\begin{array}{l}\text { Initial observation and } \\
\text { actual teaching provide } \\
\text { better experience } \\
\text { DE } \\
\text { Generic }\end{array}$ & $\begin{array}{l}38(33.03 \\
43(37.37) \\
\end{array}$ & $\begin{array}{l}0 \\
33(28.7\end{array}$ & $\begin{array}{l}0 \\
1(0.9)\end{array}$ & - & $\begin{array}{l}38 \\
77\end{array}$ & $1.30 \pm 0.045$ & 0.481 & 23.822 & 0.000 \\
\hline $\begin{array}{l}\text { Mentoring/supervision is } \\
\text { an essential asset for } \\
\text { students' } \\
\text { Learning output } \\
\text { DE }\end{array}$ & $38(20.30)$ & 0 & 0 & 0 & 38 & & & 95.029 & 0.000 \\
\hline
\end{tabular}


18 MARY ACHI MGBEKEM, EMON DUKE, EMILIA OYIRA, REGINA ELLA, AKON NDIOK, AND MARGARET ARMON

\begin{tabular}{|c|c|c|c|c|c|c|c|c|c|}
\hline Generic & $5(17.10)$ & $65(56.5$ & $5(4.3)$ & $2(1.7)$ & 77 & $1.701 \pm 0.59$ & 0.635 & & \\
\hline $\begin{array}{l}\text { TP encourages } \\
\text { professional networking } \\
\text { DE } \\
\text { Generic }\end{array}$ & $\begin{array}{l}38(33.07) \\
24(25.05\end{array}$ & $\begin{array}{l}0 \\
31(27.0\end{array}$ & $\begin{array}{l}0 \\
17(14.8\end{array}$ & $\begin{array}{l}0 \\
5(4.3\end{array}$ & $\begin{array}{l}38 \\
77\end{array}$ & $1.70 \pm 0.059$ & 0.635 & 48.515 & 0.000 \\
\hline $\begin{array}{l}\text { TP improves students } \\
\text { communication skills } \\
\text { DE } \\
\text { Generic }\end{array}$ & $\begin{array}{l}38(19.38) \\
3(16.32)\end{array}$ & $\begin{array}{l}0 \\
53(46.1)\end{array}$ & $\begin{array}{l}0 \\
15(13.0)\end{array}$ & $\begin{array}{l}0 \\
6(5.2)\end{array}$ & $\begin{array}{l}38 \\
77\end{array}$ & $1.88 \pm 0.77$ & 0.829 & 102.433 & 0.000 \\
\hline $\begin{array}{lr}\text { Mutual understanding in } \\
\text { practice } & \text { teaching } \\
\text { environment } \text { increase } \\
\text { opportunities for social } \\
\text { change } \\
\text { DE } \\
\text { Generic }\end{array}$ & $\begin{array}{l}38(20.72) \\
9(20.18)\end{array}$ & $\begin{array}{l}0 \\
59(51.3)\end{array}$ & $\begin{array}{l}0 \\
7(6.1)\end{array}$ & $\begin{array}{l}0 \\
2(1.7)\end{array}$ & $\begin{array}{l}38 \\
77\end{array}$ & $1.69 \pm 0.062$ & 0.667 & 82.111 & 0.000 \\
\hline
\end{tabular}

Note: Numbers in parenthesis are the percentage of argument in each category of 115 respondents.

With the Chi-Square statistics significant $(* * p<0.001)$, we reject the null hypothesis at 0.05 level with the probabilities less than 0.001 .

Conclusion: Nursing student experience is contingent on the Direct Entry and Generic Entry 


\section{DISCUSSION}

Professional teaching in nursing is an intentional activity that aims to facilitate learning. Specific areas or domains of knowledge and competence are compulsory for practice by nurse professionals (Nursing and Midwifery Council of Nigeria, 2008a). The domains require competent and assertive professionals who will improve and develop the domains for evidence-based care delivery. This developmental framework is reported (Moses et al, 2009, pp.175-6, Gruppen, et al, 2006) to build on healthcare professionals' existing expertise in supporting learning and encouraging further development and advancement of knowledge and competence. Findings from this study revealed that teaching practice is a valued part of nursing education that prepares students to become competent practitioners in any given context of the practice to promote good health and quick recovery.

Major themes identified in the data analysis reflected in both the questionnaire and the focused group discussions correlated with N\&MCN developmental framework. The first theme identified was adequate preparation of students for teaching practice. The student teachers in this regard posited that it was not easy to translate theory into practice while sitting as learners except with constant practice in a simulation environment. This however, they overcame with constant practice. Most of the respondents said that they found teaching very interesting as they were able to apply what they had learnt as they became conversant with the subject content. Student teachers appreciated their mentors who guided them with respect and patience as one of them commented: My mentor (class teacher) respected me even though I am a student teacher. She had patience in guiding me through the lesson plan. She ensured always that the students cooperated with me during my lesson classes. She inspired me to have confidence in myself. This kind of response indicates that the mentors were supportive and always willing to help.

Responses on teaching practice timing showed mixed feelings based on number of students within a school, availability of schools for actual classroom participation, lesson plan preparation and attendance for lectures and submission of assignments in the department.
This combination of activities is expressed as very demanding and very tiresome (Billings, \& 2008). One student was quoted as saying "it was a big challenge having to do all that at the same time. Considering the act of class control, it was observed by most of the respondents that the learners were very difficult to control. This goes to say that effective teaching/learning cannot be achieved when there is lack of discipline and moral value. This could be attributed to the fact that some of the students were contemporaries to the nursing students' teachers. One of the students commented: often the students left their cell phones on in class this I found very disruptive. This observation was reported also by Marais \& Meier, (2004, p. 223).

Teaching is a professional role of nursing (Billings \& Halstead, 2008) that comes through careful and consistent instructions to build in the learner attributes that result in academic accountability and self-efficacy to make clinical judgment to qualify within a given discipline. It prepares students to become competent practitioners who can care and instruct effectively. The art of teaching prepares nurse professionals to function as a liaison officer for students, a variety of persons or groups. During nurse preparation periods, emphasis is put on teaching activity which involves ability to understand facts essential to healthcare settings while appreciating the implications and responsibility to consequences of decision making during teaching (Bartels, 2007). In this capacity, the nurse effectively and efficiently facilitates the unrelenting crush of change through collaboration (Manion, 2011, p. 61) in care management. Teaching practice therefore is the chance for prospective nurse professionals to get into a classroom, be in charge, plan lessons and experience how to be responsible while under the supervision of a more experienced teacher (Ngidi \& Sibaya, 2003, p.18, Marais \& Meier, 2004, p. 221). However, when students on teaching practice are too many there will be likelihood of poor control, poor supervision and reduced students' class contact (Mhlongo, 1996, p. 28 McArthur-Rouse, 2008) thereby impacting on teaching and learning opportunities. A student teaching experience can be positive and beneficial, full of lessons that enables fitness for practice (Smith, 2005) or unhelpful if the students do not develop emotional and social intelligent 
competencies (Manion, 2011, p.32) to establish essential elements of a healthy relationship (trust, mutual respect, support and communication).

\section{CONCLUSION AND RECOMMENDATIONS}

Teaching practice in this study is seen as an important component of nurse education which exposes students to real life teaching and learning environment. The exercise provided students opportunity to translate theory into practice as well as gain knowledge and skills to become effective and efficient nurse practitioners in any given practice setting (American Association of Colleges of Nursing, 2008b, Berwick, 2011, Manning, 2008). Although nursing student teachers reported to enjoy the teaching practice, many challenges significantly affected their ability to employ maximally the benefits that accrue from teaching practice (Bartels, 2007, Cronewett, 2014). Based on the reported experiences, it is recommended that teaching practice handbook be provided for uniformity of writing lesson notes. Students should be exposed to micro-teaching in class before being sent to the field.

\section{REFERENCES}

Aiken, L. H., Cheung, R. B and Olds, D. M., 2009. Education Policy Initiatives to address the nurse shortage in The United States. Health Affairs 28, no 4:w646-w656. Retrieved 15/10/2014 from http://content.healthaffairs.org/content/28 /4/w646.full.html

American Association of Colleges of Nursing., 2008b. Nursing workforce development programs: Supporting the next generation of nurses and the faculty who educate them. Accessed at www.aacn.nche.edu/Government/pdf/Bro chureTitleVIII.pdf.

American Association of Colleges of Nursing., 2008c. Position statement on the preferred vision of the profession in baccalaureate and graduate nursing programs. Accessed at www.aacn.nche.edu/Publications/positio ns/preferredvision.htm.
American Nurses Association (ANA)., 2010. Nursing: Scope and Standards of Practice $\left(2^{\text {nd }}\right.$ ed.). American Nurses' Association. Silver Spring, MD

Bartels, J., 2005, January. Your career as a nurse educator. Imprint, 52, (1): 42-44.

Bartels, J. E., 2007. Preparing nursing faculty for baccalaureate-level and graduate-level nursing programs: Role preparation for the academy. Journal of Nursing Education, 46, (4): 154-8.

Berwick, D. M., 2011. Preparing Nurses for Participation in and Leadership of Continual Improvement. In: Institute of Medicine. The Future of Nursing: Leading Change, Advancing Health. Retrieved 15/10/2014 from:http;//www.nap.edu/catalog/12956.h tml 494-504

Billings, D. $M$ and Halstead, J. A., 2008. Teaching in nursing: A guide for faculty, $3^{\text {rd }}$ ed. Philadelphia: Saunders Book Company.

Broadley, M., 2008. Students' voices (and some associate reply). Early Education; 44, 1719.

Buerhaus, P., Staiger, D. O and Auerbach, D. I., 2008. The Future of the Nursing Workforce in the United States: Data, Trends and Implications. Boston: Jones and Bartlett Publishers.

Burns, $\mathrm{N}$ and Grove, S., 2009. The practice of Nursing Research: Appraisal, synthesis and Generation of evidence ( $6^{\text {th }}$ ed.). St. Louis Missouri. Saunders Elsevier.

Caputi, L and Engelmann, L., 2004. Teaching nursing: The art and science, Volumes 1 and 2. Glen Ellyn, IL: College of DuPage Press.

Concept to Classroom., 2004. Constructivism as a paradigm for teaching and learning. Retrieved from:http://www.13.org/edonlin 
e/concept2class/constructivism/index su b6.html

Cronewett, L. R., 2014. The future of nursing education. In: Institute of Medicine (IOM). The Future of Nursing: Leading Change, Advancing Health. Retrieved 15/10/2014 from: http;//www.nap.edu/catalog/12956. html 477-493.

Daniels, F. M., 2010. Response to national policy imperatives for nursing education: a Western Cape Case Study; Curationis, 33, (1): 42-48.

Dolamo, B. L and Olubiyi, S. K., 2013. Nursing Education in Africa: South Africa, Nigeria and Ethiopia Experiences. International Journal of Nursing and Midwifery; 5, (2): 14-21.

Downes, T., 2008. Student-teachers' experiences in using computers during teaching practice. Journal of Computer Assisted Learning, $\quad 9, \quad(1): 17-33$. doi: 10.1111/j.1365-2729.1993.tb00260.x.

Ferrier-Kerr., 2003. Working together: Collaborative Strategies for developing effective professional relationships in the practicum. Retrieved from: http://www.aare.edu.au/03pap/fer03456. pdf

Gruppa, I. D., Simpson, D., Searle, N. S., Robins, L., Irby, D. M and Mullan, P. B., 2006. Educational Fellowship Programs: Common themes and overarching issues. Academic Medicine; 81:990-4

Herinckx, H., Munkvold, J. P., Winter, E and Tanner, C. A., 2014. A Measure to Evaluate Classroom Teaching Practices in Nursing. Nursing Education Perspectives: January 35, (1): 30-36. doi: http://dx.doi.org/10.5480/11-535.1

Institute of Medicine (IOM)., 2001. Crossing the Quality Chasm: A New Health System for the $21^{\text {st }}$ Century. Washington DC: National Academy Press.
Kiggundu, E and Nayimuli, S., 2009. Teaching Practice: a make or break phase for student teachers. South African Journal of Education, 25: 345-358.

Lind, P., 2005. The perception of teacher education in relation to the teaching practicum, New Zealand Journal of Teachers' Work, 2, (1): 30.

Mabuda, B. T., Potgieter, E and Alberts, U. U., 2008. Student nurses'experiences during clinical practice in the Limpopo Province. Curationis 31, (1): 19-27.

Maloney, P., 2008. Planning a course. In B. Penn (ed.), Mastering the teaching role: $A$ guide for nurse educators, pp. 89-96. Philadelphia: F. A. Davis.

Manion, J. O., Morrison, $\mathrm{K}$ and Cohen., 2003. A guide to teaching practice. Retrieved from: $\quad$ www.books.google.com/books. Accessed 30th August, 2013 (23)

Manion, J. O., 2011. From Management to Leadership: Strategies for Transforming Health Care (3th ed.). San Francisco, CA Jossey-Bass.

Manning, L., 2008. Preparing students for the NCLEX-RN. In B. Penn (ed.), Mastering the teaching role: $A$ guide for nurse educators, pp. 339-358. Philadelphia: F. A. Davis.

Maphosa, C., Shumba, J and Shumba A., 2007. Mentorship for students on teaching practice in Zimbabwe: Are teachers getting a raw deal? South Africa Journal of Higher Education; 21: 296-307

Marais, P and Meier, C., 2004. Hear our Voices: Student teacher's experience during prac tical teaching. Africa Education Review, 1 , (2): 220-233. DOI:10.1080/1814662040 8566281

McArthur-Rouse, F. J., 2008. From expert to novice: An exploration of the experiences of new academic staff to a department of 
adult nursing studies. Nurse Education Today, 28, 401-408.

Mgbekem, M. A and Makoleka, C., 2008. Problem-based learning: $A$ case of Kasama School of Nursing, Zambia, West African Journal of Nursing, 16. 19, (2): 92.

Mhlongo, C. S., 1996. The role of the unit sister in teaching student nurses in Kwa-Zulu hospitals. Curationis; 9, (3): 28-31.

Moses, A. S., Skinner, D. H., Hicks, E and O'Sullivan., 2009. Developing an educational Network: The effect of a Teaching Scholars Program in the Health professions on Networking and Productivity. International Journal of Teaching and Learning in Medicine; 21, (3): 175-179.

DIO: 101080/10401330903014095

Ngidi, D. P and Sibaya, P. T., 2003. Student teacher anxieties related to practice teaching. South African Journal of Education, 23: 18-22.

Nkang, I. E., 2005. Quality Assurance in Teacher Production: The Case of Akwa lbom State College of Education, Nigerian Journal of Curriculum Studies December, 15, (1):

Oregon Consortium for Nursing Education (OCNE)., 2007. An innovative nursing education network to promote high quality, compassionate health care.

Penn, B., Wilson, L and Rosseter, R., Sept. 30, 2008. "Transitioning From Nursing Practice to a Teaching Role" OJIN: The Online Journal of Issues in Nursing; Vol 13 No 3 Manuscript 3.

DOI:
Quick, G and Sieborger, R., 2005. What matters in practice teaching? The Perception of Schools and Students. South African Journal of Education, 25: 1-4

Quinn, F. M., 2001. Principles and practice of Nurse Education (4 $4^{\text {th }}$ ed.). United Kingdom, Nelson Thrones Ltd.

Smith, L., 2005. Joys of teaching nursing. Nursing 2005. 35(1), supplement: Career Directory, 134-135.

Stover, S., 2008. What is practicum? Report on Peter Lind's keynote to At symposium. Early Education; 44:16.

Turnbull, M., 2005. Student teacher professional agency in the practicum. Asia-Pacific Journal of Teachers Education; 33, (2): 195-208.

Wagaman, J., 2010. Three Tips for Successful St udent Teacher Experiences. Htt://www.s uite101.com/blog/djwagaman.

Wanekezi, A. U., Okoli, J and Mezieobi, S. A., 2011. Attitude of Student-Teachers towards Teaching Practice in the University of Port Harcourt, Rivers State, Nigeria. Journal of Emerging Trends in Educational Research and Policy Studies (JETERAPS) 2, (1): 41-46. 10.3912/OJIN.Vol13No03Man03 
